\title{
THE PROBLEM OF REFLECTING THE MARKET IN THE LEGAL PRINCIPLES OF REAL ESTATE VALUATION IN POLAND. HOW TO ELIMINATE THE "LEGAL FOOTPRINT"?
}

\author{
Jan Konowalczuk, PhD. \\ Department of Investments and Real Estate \\ University of Economics in Katowice \\ e-mail: jan.konowalczuk@ue.katowice.pl
}

\begin{abstract}
This paper presents and subjects to criticism the current principles of real estate valuation, which were introduced in Poland in the 1990's during the return to a market economy, under the conditions of an underdeveloped real estate market. Against the background of the hypothesis of institutional maladjustment of the methodology to the current level of real estate market development, the author assesses the imitative manner of creating the valuation methodology and its discontinuation in 1998, resulting from the introduction of rigid legal regulations, which have significantly limited the ability of ongoing adjustment of the methodology to the market needs. The paper deals with the problems of defining market value and classifying valuation. The author assumes that the appraisal regarding the market value should be based on a descriptive model of real estate valuation, which should make it possible to reflect the market. He draws attention to the negative effects of valuation methodology which prevents or hinders the mapping of the market in appraisal reports. He proposes a change in the order of the legal principles of property valuation, based on a hierarchical model consisting of three elements: the definition and interpretation of value, the market and the methods of valuation.
\end{abstract}

Key words: legal principles of valuation, a descriptive valuation model, imitative standardization, the concept of "legal footprint".

JEL Classification: R30, D03, D70.

Citation: Konowalczuk J., 2017, The Problem of Reflecting the Market in The Legal Principles of Real Estate Valuation in Poland. How to Eliminate the "Legal Footprint"?, Real Estate Management and Valuation, vol. 25, no. 2, pp. 44-57.

DOI: 10.1515/remav-2017-0012

\section{Introduction}

The return to a market economy in Poland after 1989 required the creation of legal regulations that would allow carrying out the privatization process, and it was necessary to rebuild the institutions crucial for the functioning of a free and competitive market. Neo-liberal principles of the return to a capitalist economy, according to the assumptions of the Washington Consensus, were adopted at the time (WILIAMSON 2004). Hence, the fundamental role was given to market value as the basis of valuation for the majority of valuation purposes related to privatization and real estate transactions. Similarly to other sectors of the economy, the creation of a market methodology of real estate valuation was based on the imitation of the solutions used in developed market economies, hoping for the possibility of abrupt development (KLER 2010, p. 12). In the first years of the application of the imitation, very good results were achieved in creating a contemporary valuation methodology, exemplified by the professional occupational standardization. The initial lack of legal regulations allowed the professional environment centered around the Polish Federation of Valuers' Associations 
(PFVA) to develop professional standards (Standardy PFSRM 1995/PFVA Standards 1995, more in KONOWALCZUK 2011, p. 5). Later, as a result of the intervention of the State, detailed provisions of the law were implemented which governed the profession of appraisers and the property valuation methodology for all purposes and types of value, which would have previously required separate legislation (the Act of 21 August 1997, articles 7, 149, 150)1. What happened was that the State had almost completely replaced the institution of a market, which could have applied the best methodological solutions to business practice on a competitive basis. This would have enabled flexible adaptation of the methodology to the changing conditions of the real estate market. Instead of competition, however, there appeared an "unrivaled" state-imposed compulsion based on political solutions, which, for obvious reasons, are neither optimal nor stable. Above all, however, they lack the flexibility needed to keep pace with the dynamic market changes.

As a result of the dominance of the State, the imitation of the valuation methodology was considered an event of short duration, perhaps even a one-off occurrence, which is why it lacked durability and complexity. While the real estate market remained in the process of constant and increasingly dynamic changes, the processes of imitating real estate valuation methodology were stopped due to the introduction of legal principles, which have operated unchanged for over 20 years. The real estate market has since evolved in relation to the number and value of transactions and is subject to strong cyclical fluctuations. There have been major changes in the generic and personal structure of the market, as well as the financing conditions, and the motivations of investors have also become different than before. Following these changes, there emerged a problem of the absence of an effective mechanism in the legal regulations which would allow for alignment of the law with the market development and the needs of market participants, including the State. What has failed is also the mechanism of implementing changes by agreeing on new professional standards with the Minister (the Act of 21 August 1997, paragraph 175 section 6). Given the above, one could formulate a hypothesis that institutional maladjustment of the valuation methodology to the development of the real estate market has occurred and that proper adjustment is impossible unless changes are made to the current legal regulations.

This paper aims to identify the causes and partially evaluate the areas of the non-compliance of legal principles of property valuation to the principles of the market, using the concept of a "legal footprint". This term describes many situations in which there occur, unintended in legal regulations, differences between the assessments expressed in the opinions of appraisers (as well as statements of reasons presented by judges in relation to their decisions and other assessments issued by state authorities based on those opinions) and the evaluations produced by market participants. The appearance of a "legal footprint" indicates an accidental departure from the descriptive model of the determination of market value, which creates negative consequences for investors due to increased risk. This paper presents an analysis and critique of the most important methodological problems concerning the definition of market value and approaches to valuation, using the concept of the "legal footprint".

\section{Formulation of the legal definition of market value}

Legislation regarding valuation methodology in Poland was established after 1989 by using the professional standards solutions. Before the regulations, such as the Act (Act of 21 August 1997), entered into force in 1998, the professional community had had an influence on the shaping of the implementing rules (Disposition 1995) and state methodological instructions (Tymczasowe zasady/Temporary principles 1994) - an influence that was not always formal, but direct and significant. Therefore, the legal regulations introduced in 1998 represented the valuation practice applied by appraisers, which was formed under the influence of the fragmentary imitation of foreign solutions (USPAP 1994 PL; TEGOVOFA 1994 PL2; Standardy Wyceny RICS 2012/ RICS 2012 Valuation Standards).

\footnotetext{
${ }^{1}$ What was left was a narrow area of valuations free from interference from domestic provisions, e.g. on insurance value, investment value or value in use during the consolidation of agricultural land. After Poland's accession to the EU in 2004, has been obligatory to apply the European law, in particular in the area of valuation for the purposes of financial statements (Regulation EC No. 1606/2002), secured mortgage claims of banks (Regulation EC No. 575/2013) and VAT (Regulation EC No. 112/2006).

2 Polish translations of the following standards were published: Uniform Standards of Professional Appraisal Practice, Appraisal Standards Board (ASB) of The Appraisal Foundation, USA 1994 (Polish title: Jednolite standardy praktyki
} 
The regulations were created by transferring methodological solutions from standards adopted by the professional community at a level adjusted mainly to the needs of an underdeveloped market. In the system of codified law, this resulted in a gradual loss of the flexibility of valuation principles, as it was the legislation that now designated the "official" way of analyzing and assessing market phenomena. The law also began to determine the ways of interpreting the market in the context of losing the possibility to adapt to the changing needs of investors. The correctness of the legal definition of market value became problematic for valuation practices in Poland no sooner than in 2006. The dispute fully revealed itself with the adoption of the market value standard (PKZW (General National Principles of Valuation) 2009; KSWP (Basic National Valuation Standard) 1. Wartość rynkowa i odtworzeniowa/ Market and replacement value.), which had not been agreed on by the Minister. The issue has been widely discussed in relevant national literature (instead of many: KUCHARSKA - STASIAK 2012; ŹRÓBEK 2011) and a discussion was held on a professional level with the participation of scientists, mainly lawyers and economists (more in: KONOWALCZUK 2014, p. 132 et seq.). However, the dispute did not go beyond polemics, which failed to bring the parties closer to a substantive solution to the problem. Using its intrinsic power, the State has maintained the existing legal solutions without providing a methodological justification of its position.

The legal definition of market value adopted in 1998 was incompatible with the definition of the professional standard valid at the time (Standardy ...1995, Standard III.1/Standards... 1995, Standard III.1). There is also an obvious mismatch (at least editorial) between the legal definition and the European law along with the recognized international standards. At the same time, for more than 10 years, the legal system of property valuation had functioned in what could be called a methodological dualism, with different definitions contained in the Act and in the national standards. The problem of market value should be considered by taking into account its professional interpretation (Standardy ...1995, Standard III.1/ Standards... 1995, Standard III.1). A fatal error occurred in Poland in this area in terms of the imitations of European standards (TEGOVOFA 1994 PL). The error resulted from granting the methodology the features of comprehensive and universal solutions, which constituted a model for national standards. In fact, European standards related to the specific problems of the valuation of real estate as a corporate asset. The publication includes both advanced methodology, e.g. the valuation of pension fund assets, foreign enterprise assets, aa description of relations with the expert auditor, as well as simple and useful practical solutions. They were easy to adapt to the valuation practices, e.g. measuring the surface area of commercial buildings or dividing value into land and facilities. The fundamental mistake consisted in adopting methodological solutions for the measurement of the value of assets controlled by enterprises, mainly for the purpose of drawing up the balance sheet, as comprehensive and universal principles of property valuation. It seems that this could have been influenced by the utilitarian needs of the State related to the necessity of valuing the property of enterprises intended for enfranchisement, in preparation for the processes of privatization.

The solutions included in the European standards were imitated for the valuation of all types of property and, in addition to market value, the concept of replacement value was introduced, which was an unsuccessful imitation of standard No. OR 12 (TEGOVOFA 1994 PL, p. 108). Moreover, following the regulations of TEGOVOFA and USPAP standards ${ }^{3}$, the concept of market value was misinterpreted as five value types were indicated: Current Use Value (WRU), Alternative Use Value (WRA), Optimal Use Value (WRO), Forced Sales Value (WRW) and Future Sales Value (WRP). In the context of a rather inactive real estate market, having no significant power to change the use regime, market value was identified as Current Use Value. In this way, the definition of the market value was confused with one of the assumptions of valuation, related to the adopted property use.

The legal institutionalization of the valuation methodology began in 1995. The adopted regulation

zawodowej szacowania nieruchomości USA. PFSRM, Warsaw 1994 (hereinafter: USPAP 1994 PL), and the Asset Valuation Standards for Europe, The European Group of Valuers of Fixed Assets. (Polish title: Wytyczne w sprawie wyceny środków trwatych, 2nd edition, April 1988 (as supplemented in 1989 and 1992, PFSRM, Warsaw 1994, (hereinafter TEGOVOFA 1994 PL)

${ }^{3}$ The value adopted from the US standards (USPAP 1994 PL) was Future Sales Value [WRP], cf. comments to standard SMT-4 Prospective Value Estimates. Current Use Value [WRU], Alternative Use Value [WRA] and Forces Sales Value [WRW] were an imitation of TGOVOFA standards, respectively: OR 17, OR 15, W 13. The assumption of Optimal Use Value [WRO?], which was the universal principle of market valuation, did not appear in the imitated standards and was most likely taken from American literature (The Appraisal of Real Estate in 1992). 
lacks the definition of market value based on professional standards. The definition of market value is laconic: "a projected price obtainable in the market" (Order 1995, § 5 section 1). Two fundamental legal principles of valuation were introduced at the time, which were continued consistently in the subsequent years. The first principle indicated that the methods of valuation (approach) "were dependent on the assumptions related to factors affecting value that were adopted in the valuation". The second principle is the assumption that "property valuation methods are expressed in the valuation techniques" (Order 1995, §3 sections 1 and 5). This shifted the weight of the problems of valuation towards calculating the value, as the detailed contents of the appraisal requirements did not include a chapter on market analysis. Such a solution correctly reflected the conditions and possibilities of valuation on a barely active market, when finding a few transactions for comparison was considered a success. However, the theoretical error of the formulated "assumptions" is obvious, because the approach to valuation was "adopted" in a way preceding the facts on the basis of factors that are yet to be established as determinants of the searched category (value). Such an action should have a secondary retroactive character and is feasible on the basis of the results of market analysis, which should be carried out in a manner appropriate to the aim pursued. This requires a proper definition and interpretation of the sought category of market value to be formulated beforehand.

The correct solutions to these problems were included in international publications on the valuation theory (The Appraisal of Real Estate 1992 and MALINGTON 1988), and in the first Polish publications in this area (HOPFER (ed.) 1994, p. 74). The problem of the lack of market analysis was somewhat alleviated in 1998 by the introduction of an obligation to provide "an analysis of transactions on the real estate market" (Reg. of 07 July 1998, \& 4 sections 2 and 5). In 2002, the provision was altered editorially, and it was stated that the determination of value "should be preceded by an analysis of the real estate market, particularly in terms of prices paid, rental rates and conditions of the transaction" (Reg. of 27 November 2002, § 3). However, until 2004, in the provisions of the law related to the content of property valuation, the choice of the valuation method (the approach, method and technique) consistently preceded market analysis (Reg. of 07 July 1998, \& 36 and Reg. of 27 November 2002 § 52). Not until 2004 was an amendment introduced and the analysis of the real estate market was indicated in the description of the contents of the appraisal study as preceding the selection of the approach, method and valuation techniques (Reg. of 21 September 2004, § 3 and § 56). However, the amendment applied only to the content (editing) of the opinion and did not alter the general legal principles of valuation, which still deviated from the required axiological order in the market-valuemethod hierarchy.

By 1998, the legal institutionalization of the valuation methodology proceeded imitatively, from the international standards (TEGOVOFA, USPAP), through national standards, to legal regulations. Thus, the legal regulations were a derivative of the national standards' solutions. The national valuation methodology was based primarily on the technical solutions of international standards, ignoring its foundations laid in economic literature on the theory of valuation. There was no awareness that the imitated professional standards were founded on the theory of valuation, which is highly debatable due to the volatility of the economy (ADAIR et al. 1996). In terms of the description of the application of valuation methods/techniques, scientific knowledge was included fragmentarily, albeit correctly, in the valuation methodology. These solutions could not reverse the negative effects of failing to account for the foundations of the valuation theory regarding the required axiological hierarchy in the development of the legal principles of valuation, particularly in terms of understanding the role played by real estate market analysis. Since 1998, the statutory methodological regulations have specified their own criteria related to the assessment of the correctness of the methodology. This has also formalized the way professionals approach the category of market value.

\section{3. "Legal footprint" as a result of the error of premature legal institutionalization of the valuation methodology}

A legal footprint occurs when, due to legal solutions and/or professional standards, the opinion on market value cannot fully reflect the actual state of the property market, which also results in errors in the assessment of the market characteristics of the valued real estate and may mistakenly establish its competitive position. In the system of codified law, in the absence of regulations included in the professional standards, it is necessary to include not only an increasing number of laws in property valuation, but also the statements of reasons for court rulings concerning the interpretation of the 
valuation methodology principles. This concerns even the level of the "interpretation" of the concept of similar real estate and seems to be an accepted state of affairs (GACA 2016, p. 17). With the rapidly growing market, the law is not able to freely follow changes as it is stuck in its own ruts referred to as a "legal footprint"), which determine the manner and the scope of perceiving the market reality in a different way from investors. Using a language fitted to reality in order to describe the analyzed phenomena becomes difficult and sometimes impossible. Judicial interpretations contained in the statements of reasons for judgments, even at the highest competence, long experience and the best will of judges, do not follow the market.

The above can be illustrated on the example of a judgment concerning the principles of the valuation of land, which was an investment of a land developer, at the stage of its division into smaller plots. A fragment of the statement of reasons for the judgment reads as follows: "the Supreme Administrative Court [NSA] holds that there are no obstacles to the valuation of the divided plot being the sum of plots which shall make up its entirety following the division, which has implications for the choice of the size of the compared plots. In accordance with the market value of the plot, the principle of valuation, as referred to in art. 151 paragraph 1 of the Land Administration Act, requires that the valuation take into account the actual reality of the possibility of sale of smaller plots, in size following the division" (Ruling of NSA OSK 2948/2012). The problem of valuation solved by investors using the income method can be described by the Court only in the language of static price comparisons. There is no possibility to "think" using the terms relating to the valuation of investments. One can find an example in a monograph from the area of finance (KRUSCHWITZ 2007, p.2), but, above all, the provisions of law include a separate investment method, which, however, cannot be applied. The judicial justification, reasonably formulated as "the reality of sales opportunities", denotes actual problems: risk, demand, time preference, the profitability of a land development project. The scope of the formal legal terms does not allow the description of reality related to a fairly simple market situation. Appraisers and courts formulate descriptions of the subject (real estate - prices and features), while omitting descriptions of symptoms (investors' behavior). This shortcoming does not, however, produce a cognitive dissonance, as everything is resolved in compliance with the law.

The result is a "legal footprint", which complicates the valuation of a fairly simple investment, and the law does not imitate the market (investors) but creates its own, only formally correct solutions, which cannot be understood by anyone. This starts to recursively influence the decisions of market participants. In the case of a dispute, before any decision is made, everyone needs to assess whether the legal regulations are congruent to the reality of the real estate market and in what extent they may be reflected in the valuation. The legal principles of valuation that deviate from the required axiological order (value-market-method) are strengthened with the effect of the functional definition of market value and its interpretation by the Current Use Valuation [WRU], which deprives appraisers of the competence to adopt the correct assumptions for the valuation. Estimating the market value is limited to making calculations according to instructions contained within regulations or on the basis of incompetent interpretations of the law, which, in the system of codified law, entail considerable theoretical problems associated with the assessment of the scope of the admissibility of the rulemaking by enforcement organs (GOEECKI 2011, p. 21 et seq.). One may, of course, defend the interpretations of judges, whose problems with the correct interpretation of the analyzed phenomena result from the application of provisions which do not imitate the market. Expert opinions, which serve to settle disputes, may include the defect of the "legal footprint", so judges cannot compare them with other methods of valuation that could map the market directly and in compliance with the investor's way of thinking. It seems that providing a solution to this problem is conditioned by removing the effect of the "legal footprint", which justifies making changes to the law, as well as indicates the way and sets the limits of reasonable and permissible future interference of the law with the valuation methodology. The problem of the "legal footprint" in Poland concerns, in particular, the following valuation purposes: betterment levies (payable to the State in the event of property development resulting from the division and construction of public infrastructure), zoning fees charged in the event of increased property value, annual fees for the perpetual usufruct of land, real estate taxes (VAT and tax on civil law transactions), compensations for the expropriation of real estate. There is no noticeable "legal footprint" in typical private transactions, e.g. the sales and contribution of property, but it will occur in the case of litigations or administrative proceedings concerning the assessment of the effects of these transactions. 


\section{The impact of the functional legal definition of market value on the formation of valuation principles}

The legal definition of market value which has been in use in Poland since 1998 (the Act of 21 August 1997, art. 151) is functional and, unlike the known solutions included in the European and national standards and others, does not define the conditions (assumptions) of forming a price for a hypothetical transaction of the estimated property. Instead, the legal definition formulates assumptions concerning the use of transaction prices (of similar real estate) for comparison. Methodically, the market value should correspond to the ex ante approach, as this is the most probable price. Admittedly, it is related to the present, but expresses the investors' views about the future. No real estate is ever bought because of the past. Each of the parties to the transaction, especially the buyer, expresses their individual expectations for the future through the purchase, and this is done under the conditions of naturally low informational efficiency of the market (CASE, SHILLER 1989; RENIGIER-BIŁOZOR, WISNIEWSKI 2012). Value, and, at the same time, its correct determination, is perceived, ex post, as a function of (a derivative) of the comparison of historical transaction prices. In addition, historical prices used for comparisons should comply under the condition for concluding [a transaction] on a free and competitive market and, therefore, correspond to the market value of (similar) property. The analyzed legal definition includes only assumptions about conditions for making comparisons of the prices of similar property. In terms of the description of how to select property for comparison, the solution is correct and allows one to distinguish property valuation methodologically from financial valuations based solely on prices (BUM, CROSBY 1995 pp. 3-7; GRIMMSON 1985; SAYCE 2006). The legal definition of market value should be assessed as methodologically incorrect and, in fact, limited to the ex ante statement that it is "its most likely price obtainable on the market, taking into account transaction prices" (the Act of 21 August 1998, art. 151). The other elements, related to the ex post issue, do not belong in fact to the definition of market value, since they describe the assumptions of applying comparative methods in relation to the free and competitive market. Little has changed in the wording of the legal definition since 1995, and supplementing it with the conditions of comparing the prices of similar real estate is inadequate for the defined category.

However, from the legal point of view, the definition of market value meets the requirements of procedural correctness and consistency within their own assumptions and criteria. The authors of the appraisal studies based on that definition do not need knowledge or understanding of operations in the supply and demand market, as these provisions require carrying out this kind of analysis to a limited extent. The law not only formalizes and simplifies the complexity of the problems of the market but, in its own way, actually solves them according to its own normative criteria, without specifying the need to have knowledge of phenomena that actually occur at a given time. For investors, this means the creation of a significant area of regulatory risk, which appears in every conflict whose solution uses market value as the basis for valuation. Basing this category on the functional and objective understanding means that market players remain outside or at least on the margins of the analyses. It seems more suitable to approach the subject of valuation as a commodity, omitting the fact that the concept of real estate includes ownership that a specific entity is entitled to.

Given the fairly simple mathematical valuation formulas (e.g. a pair comparison or simple capitalization), there appears an impression that each person is able to determine the market value of real estate or to assess the correct use of valuation tools, since the rules are clear and quite simple in terms of application. In disputable judicial cases, appraisers' opinions are assessed by lawyers and judges not only on the formal level, e.g. regarding the correctness of the selection of similar property, but also the correct selection of market characteristics and their weights. It is assumed that any person who has learnt and understood the legal regulations becomes a valuation expert, as it may seem that these issues are clearly, comprehensively and completely regulated by law. Many believe that valuation is, in fact, a strictly legal issue, not only in the regulatory dimension, but also in terms of theoretical knowledge necessary to practice the profession. Lawyers interpret what constitutes similar property and location as a feature of the market, and there is absolutely no need for them to have expertise on the conditions of the market. The main criteria for evaluating the correctness of opinions are shifted to the technical issues of calculation, but no one is able to indicate the criteria used to settle the dispute with differently selected properties for comparison. The law attempts to replace the theory of property valuation, which is becoming less and less necessary in the area of practice. The 
acceptance of this state of affairs is just as dangerous as the assumption that, in order to assess the correctness of the construction of a building, it is sufficient to have knowledge of the construction law but no knowledge of engineering. Of course, many people can erect simple buildings or assess the correctness of their construction, and the same applies to property valuation. Without theory, disasters are bound to happen in more difficult cases, and are just as dangerous as in the construction industry, only less spectacular because without the dimension of physical destruction, the loss of the employed capital may occur. For professional activities, the law becomes not only hierarchically more important than economics, but, in fact, it becomes created as the only point of reference, and economic knowledge that is necessary for understanding the principles of market mechanisms is of little use in valuation. According to the law, what becomes completely unnecessary in the valuation process are questions about the investor (who is absent from the provisions of the law), there is no issue of the assumption relating to the adopted form of usage, there is no acceptance of the concept of optimal usage, which is determined by demand and requires the determination of how likely a change is to occur, the comparisons may not take into account the conditions of financing the purchase, and market entities simply do not exist in the process of market analysis. What suffices are price and quality - both considered "quasi-market" as neither offers the possibility of disclosure or acknowledgement of investors who, after all, make decisions related to them. This perpetuates a cognitive error, which consists in accepting that the similarity and market characteristics are properties of the very real estate, while what matters, in fact, is that the valuation rules are shaped by investors. The technical and calculation problem associated with the simple methodological procedure of explaining only the causes of price differentials in the sample (e.g. the method of pair comparison) dominates all other issues of the valuation methodology, for the market has already been "interpreted" without analysis, as one of the types of value - Current Use Value (WRU), Alternative Use Value (WRA), etc.

\section{The effects of erroneous understanding of approaches to valuation}

The scheme of valuation methods adopted in Poland is a result of the application a peculiar mix of imitative solutions adapted from the US, the UK and Germany. The classification of the valuation methods was based on the US formal recognition of approaches, but at the level of methods, a separate profits method was introduced, following the British model. The static approach to cost in valuation was taken from the German methodology. The problem with the classification of the residual method (and the costs of liquidation) required "inventing" an additional - mixed - approach. In the regulations of national standards (Standardy 1995/Standards 1995) and in the national literature, it was consistently included in the income approach (HOPFER (ed.) 1997, p. 114). In the law, it was mistakenly assumed that the methods for determining value were approaches to valuation. In the narrow methodological terms, the approaches to valuation may be considered only as a theoretical category (a concept) enabling the classification of the practical ways of valuation. This allows one to group valuation methods (techniques) by a specific criterion. An example might be a uniform carrier of value, e.g. price, income and cost, on the basis of which one can include any manner of valuation (method or technique) in one of the three approaches. In fact, in the process of valuation, the approaches to valuation serve as methods of data analysis, and not only a formula for calculating value. These are the generally accepted, comprehensive analytical solutions to valuation methodology (Wycena nieruchomości 2000, p. 104).

In addition, a legal principle for estimating property value was implemented by only one selected approach (the Act of 21 August 1998, art. 154), which had no justification in the theory of valuation, also in known publications in the Polish language (HOPFER (ed.) 1997, p. 74). The solution excluded the problem of agreeing on the results from the property valuation and led to a grotesque form of the justification of the valuation outcome in the case of valuations of real estate rarely traded on the market. The approach was associated with factors affecting the value of property. Omitted were the issues of valuation principles (KUCHARSKA-STASIAK, ŹRÓBEK 2015), applied in practice to map the functioning of the real estate market in the valuation process, which is crucial to analyze the latter properly and allows the seller and buyer behavior to be considered in the valuation process by adopting appropriate assumptions. One must note, however, that this kind of methodical solution was not the government's "idea", but only confirmed the practice of the then applied functional approach to the entire valuation process, which was based on the functional legal definition of market value. In the valuation practice, methodological solutions were developed with poor knowledge of the theory 
of economics. In the absence of own experience with valuations in developed and increasingly financialized markets, this resulted in a tendency to imitate foreign standards, mainly TEGOVOFA. Given the lack of a well-established valuation theory, it was natural to strive to formally strengthen and stabilize the methodology through law.

\section{A proposal to organize the principles of valuation using the economic analysis of law}

The introduction into the law of valuation methodology, which was immature and weak in terms of the theoretical basis, led to recurrent phenomena. The law, which normatively institutionalizes the valuation of real estate, turned professional standards into subordinated instructions. Specifically, it replaced the theory of valuation, giving the illusion of not only adequacy but also the appearance of "performing actions" for appraisers. To quote the classic, one might say, by comparison, that in these areas "reason has become an expendable piece of junk" for appraisers (BASTIAT 2015, p. 33). It has been to some extent replaced by knowledge of the law, which does not always make it possible to imitate the market, but this no longer matters in exercising a profession with legally regulated valuation principles that defend themselves formally based on own assumptions. In this situation, the problem is the lack of, or rather the asymmetry related to, cognitive dissonance. Among economists, the dissonance creates some tension and acts as a catalyst for change. Lawyers, on the other hand, fail to pick up this kind of stimuli, and asses the emerging problems as irrelevant, and are even motivated by them to defend the existing order, arguing that it is a requirement to ensure stability and legal certainty. Of course, in this case, the division into economists/lawyers has only a model meaning. It seems that the discussion regarding changes in the definition of market value held so far has been carried out without the required complexity regarding the upholding of the effects of changes for market analyses and valuation methods, as well as while maintaining the autonomy of the science of law and economics, which have different methodologies. The fruitless discussion on the problem of the correctness of the definition of market value reveals a system error concerning the malformed methodological scope of the discussion and the institutional gap regarding the absence of agreed methodological principles, common for both law and economics. One may cite here the viewpoint offered by F. A. Hayek concerning the damaging consequences of the division, which specifically concerns the two oldest disciplines: economics and law (HAYEK, 1998, p. 4). The considerations presented in this part of the publication encroach on the issues of economic analysis of law, which has not so far been applied in Poland in terms of the economics and law of real estate ${ }^{4}$.

The analysis of the applicable legal principles of valuation has shown that they are unsuited to the state of the development of the real estate market. They cannot, however, be changed by a simple imitation of the solutions used in developed markets. Neither can the problem be solved by improving technical and organizational solutions in the standards. What must be postulated in this situation is introducing evolutionary, but profound and non-imitating changes in the legislation of valuation methodology in Poland. In order to implement them, it is necessary to identify the criteria and to adopt appropriate methods of assessing the effectiveness of the new law. The lack of recommendations for solutions using simple imitations results from the existence of a permanent and strong effect of the "legal footprint". The law governing valuation methodology has been greatly incompatible with the theory of valuation for over 20 years and unsuited to the needs of the market for over a decade. The purpose of the amendments would be to introduce solutions for monitoring the market in its modern dimension, which requires taking into account the financialization of the economy (RATAJCZAK 2012; CHRISTOPHERSON et. al 2013) leading to the financialization of the real estate market, particularly housing (AALBERS 2015). Quoting Bastiat ${ }^{5}$ one may say that the existence of the valuation methodology based on the mapping of the market in its modern dimension is justified

\footnotetext{
${ }^{4}$ It seems that we may have to deal with a paradoxical situation in which one of the major economic problems, which is naturally associated with the law, is not considered, as the number of detailed regulations may lead one to the conclusion that problems on the border of law and economics are insignificant or that they do not exist at all. An overview of the national literature in the field of economic analysis of law (as well as information about other publications) is available on the website of the Polish Association of Law \& Economics - PSEAP, http://www.pseap.org/baza-zasobow-law-economics/

5 "[...]life, liberty, and property do not exist because men have made laws. On the contrary - it was the fact that life, liberty, and property existed beforehand that caused men to make laws in the first place"[BASTIAT 2015].
} 
through freedom and property, which do not result from the provisions of the law, as they surpass it, while the law is secondary in principle.

A complex approach to the methodology allows one to identify different ways of organizing and establishing the hierarchy of the basic elements forming the principles of valuation. The possible ways of organizing these principles have been presented in Table 1.

Table 1

The possibilities of hierarchical ordering of valuation principles

\begin{tabular}{lcccc}
\hline $\begin{array}{c}\text { Name of Order/ } \\
\text { Criteria }\end{array}$ & Normative & Positive & Instrumental & Functional \\
\hline Essence & Value & Market & Method & $\begin{array}{c}\text { Value as the } \\
\text { function of prices }\end{array}$ \\
\hline $\begin{array}{l}\text { Analysis } \\
\text { Environment }\end{array}$ & Market & Method & Market & Method \\
\hline Algorithm & Method & Value & Value & Market \\
\hline
\end{tabular}

Source: Own study.

The legislation introduced a functional order of valuation principles in Poland according to the following hierarchy: value (as a function of prices) - method - market. Ultimately, the following axiological normative order ought to be implemented:

1) (Value). The definition of market value and its professional interpretation.

2) (Market). Assumptions concerning market analysis, taking into account the valuation principles, including the analysis of optimal use or another procedure implementing a descriptive model for determining market value.

3) (Method). The methods of valuation representing computational formulas, known as techniques or methods.

The above requires changing the definition of market value along with a comprehensive amendment of other laws that should change the hierarchy and place the market and its analysis before valuation methods. This kind of arrangement opens up opportunities and introduces the need for an analysis of the usage of appraised real estate against the conditions of competition in the market. It will be possible to take full advantage of the concept of the highest and best use (HBU), which has been known in the US for almost 100 years. New issues of key importance will include market segmentation for the purposes of valuation (SMITH, KROLL 1988; BOURASSA et. al 1997), which should take into account the demand approach towards real estate (WATKINS 2001), derived from the consumer theory for the household market (LANCASTER, 1966). What will remain are specific problems of market segmentations, representing the assets of enterprises and public property. This opens up a very broad area of discussion in the valuation practice regarding the evaluation of the usefulness of qualitative (e.g. taxonomic) methods, but, above all, one will be able to count on the support of statistical methods, in particular those related to the proper use of regression analysis (BARAŃSKA 2002; ISAKSON 1988).

The area of positively organized valuations (market-value-method) shall remain a domain of financial valuations (appraisals) related, e.g., to risk management of financial instruments based on mortgages, especially in the case of their securitization. It seems that the only arrangement to be rejected is the instrumental one (method-market-value), which was used in financial valuations with assumed informational efficiency of the real estate market. Resignation from the functional order and rejection of the instrumental one leaves only two competing arrangements of valuation principles:

- the normative one, which is appropriate for property appraisal,

- the positive one, which is used in financial appraisals leading to the determination of investment value (BUM, CROCBY 1993, pp. 3-7).

Given the above, there appears an apparent contradiction associated with the recommendation of ordering the methodology for property valuation by means of the normative order, while market value should correspond to the descriptive model stemming from positive economics. First of all, it must be noted that the proposed methodological arrangement concerns the entire issue of property valuation. A comprehensive approach requires that, in addition to market value, which is to provide market objectification and for this reason is of a descriptive nature, other valuation bases also be provided. The assumptions of their definition shall differ from typical market conditions, hence their 
subjective character. Subjective valuation bases result from practical needs and are variable due to the ongoing adaptation to the current needs of the economy. They are usually an expression of the interference of the State in the functioning of the market and shape the way of performance and the scope of property protection. An example of current practices in this regard may be introducing the basics of equitable value (IVS104: Bases of Value). Previously recommended were the following subjective values: indemnification, bank and mortgage, functioning business value, tax or cadastral, special, recovery, forced sale and liquidation, investment, and individual, use value (IVS 2005 PL, pp. $31,43-44,85-103)$. In this perspective, market value is descriptive, which means its determination shall be based on the hypothesis of the most probable price. It shall differ from financial valuations not only in terms of valuation methods, but, first and foremost, in terms of the method of performing market analyses. In the case of real estate, each of which is different, it becomes necessary to perform an individual estimate of value, which constitutes the basis for negotiating and agreeing the price for both the seller and the buyer (GRISSOM 1985; DIAZ 1990). Financial appraisals of real estate do not require segmentation of the market from the perspective of demand, since there is an assumption of the homogeneity of marketing items, often accompanied by an additional assumption of the efficiency of markets. This assumption is not used in estimating property value, and the level of efficiency is mapped in market value (as the basis of valuation), taking into account the current state of the supply and demand (im)balance at different levels of informational efficiency. It is satisfying for buyers and sellers inasmuch as the transactions are concluded in free market conditions. In the practice of property valuation, the descriptive character of market value is carried out primarily at the level of the specificity of performing market analyses, and is followed by the application of adequate, fairly simple valuation methods. However, this is preceded by the normative definition and interpretation of an appropriate valuation basis with the key category of market value.

\section{Conclusions}

Introducing changes in the valuation methodology shall be extremely difficult because of the line of defense of the legal solutions which have been in operation for almost 20 years will be based on the area of legal effectiveness (STELMACH, SONIEWICKA 2007, p. 42). This is a criterion entirely sufficient for the State to defend the regulations in force. This means that the conclusions are formulated based on the results of the analyses of solely formal legal consequences ${ }^{6}$ of specific regulations, which limits the consideration of the problem to the assessment of the effects of passed judgments or issued administrative decisions, with no one carrying out evaluations for private investors or assessing the changes in the operational conditions of the market. However, it should be assumed that the evaluation of existing legislation, for instance regarding the correctness of the definition of market value and the remaining organization of valuation principles, should apply to the extent of the implementation of the objectives set by the acting party. Analysis limited to the formal range should be deemed as lacking the assessment of actual effectiveness. Formal analysis is sufficient for the State, which defends the regulations as it organizes information based on "what can be seen". In order to reach "what cannot be seen" (as in the parable of the broken window, BASTIAT 2015a), it is necessary to analyze the actual efficiency, which, until now, has not been a subject of discussion.

Although, in terms of theory, the economic order is ahead of the law, we are not dealing with an original situation, but only with an economy functioning in real terms and dominated by the law that leaves a "footprint". Therefore, no initial conditions are created, but one merely seeks the best adjustment of the existing conditions to the hierarchical order, based on efficiency concepts that are accepted by the law and expected to form a hierarchy. This requires designing discussion areas anew and indicating appropriate methodological tools to be applied in order to study the principles of property valuation. At the outset, one must overcome the "pernicious division" into disciplines of law and economics, which have different methodologies. The solution is to integrate the discussion at the level of the methodology of the economic analysis of law. In the Polish conditions of real estate economy, this is a pioneering project that could not only lead to the development of correct valuation principles, but also solve the problem of the necessary flexibility in the law regulating this issue. It would be a contribution to a broader discussion on the effectiveness of the applied legislation in real

\footnotetext{
${ }^{6}$ A term more commonly used in literature is "normative consequences." The author of the publication uses the phrase "formal consequences" in order to avoid associations with the normative order of the valuation methodology.
} 
estate management, which shapes the exclusivity of real estate ownership through legal regulations. An example may be the assessment of the regulation regarding the collection of a zoning fee only if property is sold within five years of the change of the zoning plan. One could raise the problem of the impact of such a regulation on market efficiency and, alternatively, consider a contrary solution, i.e. exemption from the fee only in the sales period of up to five years. Each of these solutions has a different impact on the efficiency of the real estate market, and also affects the effectiveness of municipal investment in infrastructure. Thus, we return to the question of ordering the principles of property management by indicating the degree of achievement of the objectives set by the acting party - in this case, the State. It should be assumed that maladjusted (bad) law can be harmful and the damage done can be measured quantitatively or qualitatively. After combining the theory of law and economics, it can be assumed that the efficiency will mean such creation and application of the law that will maximize prosperity for the largest possible number of people, minimize the harm and/or imitate the market behavior in the best possible way (CHRUPCZALSKI 2008, p. 23). In any case, the key is to determine the criteria based on which this type of assessment will be carried out.

The results of the study allow the formulation of the following detailed proposals:

1) The methodological concepts of real estate valuation in force in Poland are not suited to the development of the market and the needs of investors.

2) The initially successful attempt made in the 1990s to develop a valuation methodology in Poland by imitating the solutions of foreign standards was stopped by the introduction of rigid legal regulations. The legal institutionalization of valuation methodology introduced in 1998 was tailored primarily to the needs and objectives pursued by the State (mainly privatization). It should be considered premature, fragmentary, and suited only to the conditions typical for the emerging real estate market.

3) The maintenance of the still dominant concept of property valuation, based on the assumption of the functional definition of market value and the Current Use Value (WRU), has no theoretical justification and does not correspond to the level of market development, which not only allows the allocation of ownership, but also helps improve utilization of real estate resources through changes in the manner of usage.

4) Simple imitative ways of creating rules for valuation of real estate in Poland should be considered exhausted. It is necessary to implement a methodological change consisting of the integration of approaches to real estate in law and economics. It seems reasonable, therefore, to apply the economic analysis of the law in order to design legal principles of valuation which, in the case of using a basis concerning the market value, will enable the monitoring of the market, even under conditions of more dynamic changes.

5) It is recommended to introduce a normative order of valuation principles used in estimating market value based on the value-market-method hierarchy. This requires resignation from the functional definition of market value and a comprehensive change of other provisions, which should change the hierarchy and place the market and market analysis before valuation methods.

The hypothesis of the institutional maladjustment of the valuation methodology to the level of the development of the real estate market in Poland has been positively verified. The proposal recommending the introduction of non-imitative changes in the legislation regarding the valuation methodology in Poland requires further research in terms of applying economic analysis of the law, which induces the exploration and analysis of various criteria for assessing the effectiveness of law that can be used for ex post analyses and ex ante evaluations when designing changes in the legislation.

\section{Literature}

AALBERS, M.B., 2015, The Great Moderation, the Great Excess and the Global Housing Crisis. Journal of Housing Policy 15(1), pp. 43-60.

AdAIR A., DOWNIE M.L., MC GREAL ,S., VOS G., 1996, European Valuation Practice: Theory and Techniques, London, New York.

BANASZCZYK Z., 2013, [IN:] Kodeks cywilny. Tom I. Komentarz (The Civil Code. Vol. 1. Commentary) [in Polish]. Warsaw 2013,

BARAŃSKA A., 2002, Kryteria stosowania modeli stochastycznych w predykcji rynkowej wartości nieruchomości, Zastosowania metod statystycznych $w$ badaniach naukowych (Criteria for the Use of 
Stochastic Models in the Prediction of the Market Value of Real Estate, Applications of Statistical Methods in Scientific Research) [in Polish], www.statsoft.pl/czytelnia.

Bastiat F., 2015, Co widać i czego nie widać (What is Seen and What is Unseen), translated by A. Łatka, Prohibita, Warsaw.

Bastiat F., 2015a, Prawo/The Law, translated by P. Toboła-Pertkiewiecz, Prohibita, Warsaw.

Bum A, CRosby N., 1995, Property Investment Appraisal, 2 ed., Routledge, London - New York.

Bourassa, S. C., HAMElinK F., Hoesli M., MAC GREGOR B. D., 1997, Defining Housing Submarkets Journal of Housing Economics.

Christopherson S., MARTIN R., POllard J., 2013, Financialisation: Roots and Repercussions, Cambridge Journal of Regions, Economy and Society November 1 (6), pp. 351-357.

CEllmer R., Foryś I., KONOWALCZUK J., KRAJEWSKA M., KUCHARSKA-STASIAK E., PARZYCH P., TANAŚ J., TROJANEK M, WóJCIAK E., ŹRÓBEK S., 2015, Real Estate Valuation for Special Purposes, Nacionalna Knjižnica, Zagreb, Dostęp 16.02.2016, http://gis.us.edu.pl/index.php/past-gis-conferences/22-gisodyssey-2015/book-1

Claessens s., Kose M. A., Terrones M. E., 2011, Financial Cycles: What? How? When?, Working Paper 11, International Monetary Fund, Access 10.02.2016, https:/ / www.imf.org/external/pubs/ft/ wp/2011/wp1176.pdf

CASE, K. E., SHILLER R. J., 1989, The Efficiency of the Market for Single-Family Homes, American Economic Review, 79, pp. 125-137.

DiAZ, J., 1990, How Appraisers Do Their Work: A Test of the Appraisal Process and the Development of a Descriptive Model. The Journal of Real Estate Research, November, Spring, Vol. 5, issue 1, pp. 1-15.

Dyrektywa Rady 2006/112/EW - Unijny wspólny system podatku od wartości dodanej (VAT) (Council Directive 2006/112/EC - on the common system of value added tax).

FANNING S. F., 2005, Market Analysis for Real Estate. Concepts and Applications in Valuation and Highest and Best Use. Appraisal Institute. Chicago, Il.

GACA R., 2016, Interpretacje pojęcia nieruchomość podobna (Interpretations of the Concept of Similar Property) [in Polish], Rzeczoznawca Majątkowy No. 1(89), PFRSM, Warszawa. PFRSM, Warsaw.

Grissom, T.V., 1985, Value Definition: its Place in Appraisal Process, "The Appraisal Journal", April.

GOŁECKI M.J., 2011, Między pewnościa a efektywnością. Marginalizm instytucjonalny wobec prawotwórczego stosowania prawa (Between certainty and efficiency. Institutional marginalism versus the rulemaking application of the law) [in Polish], Lex a Wolters Kluwer business, Warsaw.

HAYEK F. VON, Law, 1979, Law, Legislation and Liberty a New Statement of the Liberal Principles of Justice and Political Economy, Routledge \& Kegan, London, Reprinted 1993, 1998, http:/ / www.libertarianismo.org/livros/lllfh.pdf, access 6.03.2016.

Hendriksen E. A., BredA M. F., 2002, Teoria rachunkowości (Accounting Theory) [in Polish], PWN Warsaw 2002.

HOPFER A. (RED), 1997, Wycena nieruchomości i przedsiębiorstw (Valuation of Real Estate and Enterprises) [in Polish], Vol. 1, Twigger SA, Warsaw.

Hopfer A., (red), 1993, Wycena nieruchomości. Przykłady (Valuation of Real Estate. Examples) [in Polish]. Wydawnictwo ART., Olsztyn.

ISAKSON, H. R., 1988, The Review of Real Estate Appraisals Using Multiple Regression Analysis. Journal of Real Estate Research, Vol. 15, issue 2, pp. 177-190.

IVS104: Bases of Value, Exposure Draft, 2016, International Valuation Standards Council, London, 7 April 2016, https:/ / www.ivsc.org/files/file/view/id/646, accessed 15.05.2016

Jednolite standardy praktyki zawodowej szacowania nieruchomości USA (Uniform Standards of Professional Appraisal Practice USA) [in Polish] PFSRM, Warszawa 1994, Appraisal Standards Board (ASB) of The Appraisal Foundation, USA 1994).

KLER J., 2013, Rozwój imitacyjny: zalety i wady (Imitative Development: Advantages and Disadvantages) [in Polish], publikacja IX Kongresu Ekonomistów Polskich, (a publication of the 19th Congress of Polish Economists), accessed 10.03.2016 http://docplayer.pl/2062666-IX-kongres-ekonomistowpolskich-patronat-honorowy-prezydenta-rzeczypospolitej-polskiej-bronislawakomorowskiego.html.

KonOWALCZUK J., 2011, Standaryzacja wyceny nieruchomości w Polsce (The Standardization of Real Estate Valuation in Poland) [in Polish], Świat Nieruchomości, issue 76, p. 5. 
KONOWALCZUK J., 2014, Wycena nieruchomości do celów kredytowych (Real Estate Valuation for Lending Purposes) [in Polish], Poltex, Warsaw.

KRUSCHWITZ L., 2007, Finansowanie $i$ inwestycje (Financing and Investment), CeDeWu, Warsaw.

KUCHARSKA-STASIAK E, 2012, Wycena bez wartości - przyczyny i skutki (Valuation with no Value - Causes and Efects) [in Polish], Studia i Materiały TNN, Vol. 20, Issue 2, Olsztyn.

KuCHARSKA-STASIAK E., ŹRÓBEK S., 2015, An Attempt to Exemplify the Economic Principles in Real Property Valuation, Real Estate Management and Valuation, Vol. 23, No. 3, pp. 5-13.

LANCASTER, K., 1966, A New Approach to Consumer Theory. Journal of Political Economy, Vol. 74, No. 2 (Apr.), pp. 132-157, http:/ / www.jstor.org/stable/1828835, access on 5 July 2016.

MaLington A.F., 1988, An Introduction to Property Valuation, London.

Międzynarodowe Standardy Wyceny 2005, wydanie polskie (IVS 2005 PL) (International Valuation Standards 2005, Polish edition (IVS 2005 PL)) [in Polish], 2006, Polska Federacja Stowarzyszeń Rzeczoznawców Majątkowych/Polish Federation of Valuers' Associations, Warsaw.

Podejścia, metody i techniki szacowania. Materiaty szkoleniowe (Approaches, Methods and Techniques of Valuation. Training Materials) [in Polish], 1993, Promiks, Katowice.

Powszechne Krajowe Zasady Wyceny (PKZW 2008) (General National Principles of Valuation (PKZW 2008)), PFSRM, Warsaw. www.pfva.com.pl.

RATAJCZAK M., 2012, Finansyzacja gospodarki (The Financialization of the Economy) [in Polish], Ekonomista, 2012 Issue 3, pp. 281-302.

RENIGIER-BIŁOZOR, M., WiśNIEWSKI, R., 2012, The Effectiveness of Real Estate Market Versus Efficiency of its Participants, Uropean Spatial Research and Policy, Vol. 19, No. 1.

Rozporządzenie Parlamentu Europejskiego I Rady (UE) nr 575/2013 z dnia 26 czerwca 2013 r. w sprawie wymogów ostrożnościowych dla instytucji kredytowych i firm inwestycyjnych. (Regulation (EU) No. 575/2013 of the European Parliament and of the Council of 26 June 2013 on prudential requirements for credit institutions and investment firms).

Rozporządzenie Rady Ministrów z dnia 21 września 2004 r. w sprawie wyceny nieruchomości i sporządzania operatu szacunkowego (Ordinance of the Council of Ministers of 21 September 2004, on the Appraisal of Real Estate and the Preparation of Property Valuation Report) Dz.U. 2004 nr 207 poz. 2109 ze zm. (Journal Of Laws, No. 207, Item 2109, as amended).

Rozporządzenie Rady Ministrów z dnia 27 listopada 2002 r. w sprawie szczegółowych zasad wyceny nieruchomości oraz zasad i trybu sporządzania operatu szacunkowego (Ordinance of the Council of Ministers of 27 November 2002, on the Detailed Principles of Appraisal of Real Estate and the Principles and Method of the Preparation of Property Valuation Report), Dz.U. 2002 nr 230 poz. 1924. (Journal Of Laws of 2002, No. 230, Item 1924, as amended).

Rozporządzenie Rady Ministrów z dnia 7 lipca 1998 r. w sprawie szczegółowych zasad wyceny nieruchomości oraz zasad i trybu sporządzania operatu szacunkowego (Ordinance of the Council of Ministers of 7 July 1998, on the Detailed Principles of Appraisal of Real Estate and the Principles and Method of the Preparation of a Property Valuation Report), Dz.U. 1998 nr 98 poz. 612. (Journal Of Laws of 1998, No. 98, Item 612).

SAYCE S. et al., 2006, Property Appraisal: From Value to Worth, Blackwell Publishing, Oxford.

SMith, C.A., KROLL M.J, 1989, Utility Theory and Rent Optimization: Utilizing Cluster Analysis to Segment Rental Market. The Journal of Real Estate Research, Vol. 4, issue 1, pp. 61-67.

Standardy Wyceny RICS 2012/RICS 2012 Valuation Standards, 2012, PFSRM, Warsaw, March.

Standardy zawodowe rzeczoznawców majątkowych (Professional Standards of Real Estate Valuers) [in Polish], 1995, PFSRM, Warsaw.

The Appraisal of Real Estate, 1992, Thent Edition. Chicago.

Tymczasowe zasady wyceny nieruchomości (Temporary principles of real estate valuation) [in Polish], 1994, Ministerstwo Gospodarki Przestrzennej i Budownictwa, Warszawa. (The Ministry of Spatial Planning and Construction, Warsaw).

WATKINS, C., 2001, The Definition and Identification of Housing Submarkets. Environment and Planning A, Vol. 33, pp. 2235-2253, http:/ / citeseerx.ist.psu.edu/viewdoc, accessed 16 June 2016.

Williamson J., 2004, A Short History of the Washington Consensus, Paper commissioned by Fundación CIDOB for a conference "From the Washington Consensus towards a new Global Governance," Barcelona, September 24-25, 2004, https://piie.com/publications/papers/williamson0904-2.pdf, accessed 3 May 2016. 
Wycena budynków. Poradnik, materiaty pomocnicze. Nieruchomości (Valuation of buildings. Guidance, support materials. Real estate) [in Polish], 1993, WACETOB, Warsaw.

Wycena nieruchomości/The Appraisal of Real Estate, 2000, Wydanie polskie/Polish edition, PFSRM, Warsaw.

Wytyczne w sprawie wyceny środków trwatych (Guidelines on the Valuation of Fixed Assets) [in Polish], 2nd edition, April 1988 (as supplemented in 1989 and 1992, PFSRM, Warsaw 1994, (Asset Valuation Standards for Europe, The European Group of Valuers of Fixed Assets).

Zarządzenie $\mathrm{w}$ sprawie szczegółowych zasad ustalania wartości nieruchomości (Ordinance on detailed rules for determining real estate value), 1995, Ministra Gospodarki Przestrzennej i Budownictwa z dnia 1 marca 1995 r.. Monitor Polski z 1995 r., nr 13 poz. 163. (of the Minister of Spatial Planning and Construction, of 1 March 1995, Monitor Polski of 1995, No. 13, item 163. Warsaw).

ŹRÓBEK S., 2011, Sposób optymalnego użytkowania nieruchomości - ujęcie definicyjne i metodyczne (The highest and best use of property - a definitional and methodological approach) [in Polish], Studia i Materiały TNN, Vol. 19, No. 1, Olsztyn. 